\title{
Study on the Development of Agricultural Economy in Zhou Li
}

\author{
Dandan Qi
}

Institute of Business Economy, Harbin University of Commerce, Harbin 150028

\author{
Keywords: Zhou Li; Agriculture; Management
}

\begin{abstract}
Zhou Li of the pre-Qin Dynasty records the early agricultural production technology communication, reflecting the Warring States period of China's agricultural management of the relevant information. On the basis of the previous research results, this paper discusses the object, the way and the main content and the supervision mechanism of the agricultural skill education contained in Zhou Li. Although the Zhou Li records with a certain idealized color, but through the Zhou Li see the agricultural skills of historical data analysis, and with other pre-Qin literature and unearthed data comparison, we found Zhou Li related Records, a more comprehensive reflection of the pre-Qin period, especially in the Spring and Autumn Period to the Warring States period of agricultural management situation, we can deepen our Spring and Autumn Period during the development of agriculture to further understand the situation.
\end{abstract}

\section{Introduction}

Zhou Li more emphasis on the introduction of agricultural production, Da Zai Jiu Zhi said the slaughter of nine categories of professional appointment of the people, the first is in three different terrain in agriculture, the production of various cereals. The second is Park. The third is the industry of $\mathrm{Yu}$ Heng, the development and utilization of mountains, rivers and so on. The fourth is the number of animal husbandry industry, breeding birds and animals. The Great SITU distributes twelve occupations to the people so that they are engaged in their own occupations[1]. The first is the kind of grain, the second is the kind of fruit, the third is the development of mountain Chuanze material, the fourth is animal husbandry, the fifth is the next industry, the sixth is the business, the seventh is the textile industry, the eighth is the collection industry, the ninth is to learn Taoism, the eleventh is handed down from generation to generation, the twelfth is in the official service[2]. The first few of the twelve precepts of the Stuart are related to agricultural production. Before the spring plowing, the emperor and in their respective fields in the excavation, on the one hand that the importance of agriculture; the other hand, played a role in the education of officials and farmers[3].

\section{The Main Object of Agriculture}

Zhou Li recorded in the main object of agricultural education there are two categories. One is the farmer, the second is the farmer. "Zhou Li" agricultural officials as the object of agricultural education, because they are responsible for the specific responsibilities of farmers. "Zhou Li" as the main officer of the official system officials. Their ministry involves the cultivation of fields of technology, the cultivation of fruit trees, the harvesting techniques of forest materials, the techniques of collecting wild fruits, the techniques of feeding birds and animals, and so on[4].

According to Zhou Li, there are three main forms of agricultural skills: The first is official officer. Zhou Li clearly pointed out that the responsible for the transfer of agricultural technology officials for the world. Second, the official to the people. Grassroots officials bear the responsibility of the people to cultivate and persuade the people to cultivate. agricultural education in $\mathrm{Zhou} \mathrm{Li}$ is basically in the production of labor to complete the process. Teaching in the fields is an important way of agricultural education[5]. This way of teaching is more intuitive and practical. Third, the people of the people's education. Experienced seniors have the experience and lessons learned in the production practice, through personal demonstration and oral explanation to the way to other people, this way intuitive and easy to learn. 


\section{Investigation of Agricultural Skills}

Agricultural production technology for the performance of the soil, the knowledge of astronomical calendar knowledge and farming techniques such as farming. For this series of technical guidance and teaching, the state has a special department to manage, and in the form of laws to spread to farmers, to guide agricultural production.

\section{Knowledge of the Soil}

Zhou Li recorded in the teachings of people to identify and improve the soil content. Zhou Li has a study of different areas of soil suitable for planting what kind of crop of the official, such officers mainly include the official SITU, the official grass and the summer official soil and so on. The use of the law should have the ancient origin. The great SITU taught the people according to the law of the past, and identified the people and things that were suitable for the growth of the five terrain. The Stewart also taught the people to identify 12 kinds of soils suitable for planting crops, in charge of the world map and record the number of population and household registration number. The above duties of the Stuart decided that he was the most suitable candidate for the implementation of agricultural education to the people.

In addition to the great Stuart, the teachings of the soil should be the law of the land of the grass and the summer official soil. Zhou Li official grass main functions to improve the soil, enhance the soil fertility, to study the soil situation suitable for planting what kind of crops. Summer official soil and grass people each other official, study improved soil method, and will be granted to the land.

Zhou Li on the local officials at all levels to the soil of the law to teach people to raise the requirements of farming, but also requires local officials to encourage people to learn from each other, the exchange of soil should be the law and farming experience. Let the peasants learn the law of the soil, sum up the experience and keep it. To make outstanding contributions to the people, to be rewarded. It is also one of the main criteria for investigating and judging the performance of local officials.

\section{Astronomical Calendar Knowledge}

According to Zhou Li in the central, TaiZai general astronomical calendar, responsible for the revision of the year, TaiZai in charge of astronomical observations, study the preservation of a large number of occupied days of the map. Arrange the people at four o'clock farming and life, that is, "the age of the preface," and promulgated to the official and despicable, but also to the princes promulgated the next year. To determine the leap month, to declare the king in this month how to deal with government affairs.

Zhou Li contained in these astronomical calendar knowledge is mainly used in agricultural production. In addition, it is also used to measure the land, determine the position to meet the needs of military operations. Even in order to build the country, but also with the "craftsmen" to learn the use of the method to measure the four parties, which shows that in the "Zhou" in the astronomical calendar education is more developed.

\section{Farming Skills}

Zhou Li to the official of all levels of local magistrate every year to their people and teach the food farming. The slaves themselves are the creators of social production and the means of subsistence, and it is necessary for them to teach agricultural technology. The officer is in charge of the kingdom of the wild. According to the map division field, the development of county division of the division. According to the people of the four seasons of the year, to give them the fields, to review their weapons and equipment, to teach them to grow crops. Then the officials have a clear educational responsibilities. In the middle of the people is not uneducated, but to accept different from the slave owners aristocratic another education in the educational content and the degree of education and the 
education of the township are significantly different, mainly in agricultural technology education, Therefore, the teaching can not be ignored.

\section{The Supervision Mechanism of Agricultural Skills}

In order to ensure the normal commencement of agricultural activities, Zhou Li rovides that the local administrative organizations of the officials have the responsibility of the church and the church and the prohibition of the ban. Zhou Li on the management of agricultural production and transfer of agricultural skills to monitor the officials. The number of the six animals, the number of fields, and the number of men and women in recognition of the meritorious people, gathered at all levels to teach them to do the work. Those who govern the city officials, warned them to work the focus, and accordingly to their reward, punish, remove or lift.

The small SITU judge the governance of the four suburbs of the six townships, regulate their political affairs, examine the fields and the number of people, six animals, weapons and equipment, pending the state issued the relevant decree. Zhou Li provides that the local officials have the responsibility to encourage people to do a good job of farming, in the busy occasion of civil engineering, not the issue of military affairs. Common people of the adult ceremony, married, enjoy the worship of wine and other things need to be confused, so as not to impede farming. Qin Tomb Bamboo Slips stipulates not only in charge of agricultural farming matters, but also responsible for the management of farmers to maintain the basic order of life in order to ensure the smooth progress of agricultural activities.

To sum up, through the Zhou Li from materials analysis, we can see the country has a special department and specialized officials of the agricultural production management, and agricultural production skills, such as soil awareness, astronomical calendar knowledge and farming And other agricultural production technology, in the form of laws to teach farmers, to guide agricultural production. And with the corresponding supervision system to ensure that China's Spring and Autumn during the Warring States period the further development of agriculture.

\section{References}

[1] Sun Yirang. Zhou Li justice [M]. Beijing: Zhonghua Book Company, 1987.

[2] Wang Zhao Yu. Zhou Li detailed solution [M]. Wenyuan Ge four treasures of the book. Shanghai: Shanghai Ancient Books Publishing House, 1987.

[3] Yun Lu and other essays. Order of Zhou Guoyi sparse [M]. Tianguan mound killed the first two. Wen yuan Ge four treasures of the book. Shanghai: Shanghai Ancient Books Publishing House, 1987.

[4] Sun Xidan. Book of Rites [M]. Beijing: Zhonghua Book Company, 1989.

[5] Li Xiangfeng. Pipeline Note [M]. Beijing: Zhonghua Book Company, 2004. 